\title{
積層ゴム支承の終局特性に関する実験及び解析的研究 \\ 高減衰ゴム系積層ゴム支承の終局特性予測のための材料モデル提案と破断及び座屈予測解析 \\ EXPERIMENTAL AND ANALYTICAL STUDY ON ULTIMATE PROPERTY OF RUBBER BEARINGS
}

Proposal of material model to predict ultimate property and prediction analysis

of break and buckling property for high-damping rubber bearings

森＼cjkstart隆浩*1, 室田伸夫*2

Takahiro MORI and Nobuo MUROTA

\begin{abstract}
Rubber bearing is one of measure isolation devices. Rubber bearings support upper structure under high vertical loading, therefore, it is very important to understand ultimate property and margin to the ultimate state to design seismically isolated structures properly. However, it is difficult to carry out ultimate property test using full-scale specimen because large scale testing machine is needed. One of the alternative method to predict performance of rubber bearings is analysis approach and finite element analysis is one of the most popular methods. Therefore authors propose analysis model to predict ultimate property of rubber bearings based on finite element analysis.
\end{abstract}

Keywords : High-Damping Rubber Bearings, Seismic Isolation, Ultimate Property, Material Model, Finite Element Analysis, Second Shape Factor 高減衰ゴム系積層ゴム, 免震, 終局特性, 材料モデル, 有限要素解析, 二次形状係数

1. はじめに

近年、防災に対する関心の高まりにより、特に高層建物を中心に 建築物の免震化が進んでいる。それに伴い、積層ゴムに代表される 免震装置における大地震時の効果も実証されつつある。積層ゴムは 建物を支える重要部材であり、積層ゴムの終局特性に対して十分な 余裕をもって免震建物を設計する必要がある。故に、積層ゴムの終 局特性とその余裕度を把握することは非常に重要である。しかしな がら、積層ゴムは建物の大荷重を支える大型の装置であるため、実 大試験体による終局特性の把握には大規模試験機が必要であり、そ の試験実施は容易ではない。終局特性把握試験の代替手法として、 解析による終局特性の予測が挙げられる。本研究は、終局特性を高 精度に表現可能な解析モデルの提案を目的とする。解析による特性 予測の有用な手法としては、有限要素法(以下、FEM)が挙げられ、 本研究でも FEM を用いて積層ゴムの終局特性を予測する。

積層ゴムの終局モードには、鉛直荷重を受けた状態で水平大変形 した際の積層ゴムの破断(以下、せん断破断)、同じく鉛直荷重を受け た状態で水平大変形した際の荷重支持能力喪失(以下、座屈)、過度な 引張変形を受けた際の破断(以下、引張破断)、過度な鉛直荷重を受け た際の破断(以下、圧壊)など多岐にわたる。せん断破断及び引張破断 は主にゴムの破断であるが、圧壊は鋼板の破断であることが知られ ている 1)。特にせん断破断及び引張破断に関しては、一般に、内部 鋼板とゴムの接着剥離ではなく、ゴム破断であることが要求される。
また、多段積層ゴムのように特殊な形状の積層ゴムで顕著にみられ る終局モードとして、鉛直荷重を受けた状態で水平大変形した場合 でも積層ゴムの一部に大きな引張変形を生じ、局所的には引張破断 とみなせるようなケースもある 2)。更に、上下躯体をボルトなどで 締結されていない積層ゴムにおいては「ロールアウト」も終局特性 となりうる3)。本研究では、様々な終局特性の中でも特に重要と考 えられる「せん断破断」、「引張破断」「座屈」の 3 つに注目し、既 往の研究における「せん断破断ひずみ」、「引張破断ひずみ」、「座屈 ひずみ」の FEM による判定手法を適用し、それらの終局特性を FEM で予測する。

積層ゴムには、天然ゴム系積層ゴム、鉛挿入型積層ゴム、高減衰 ゴム系積層ゴム、弾性すべり支承など様々なタイプが存在するが、 本研究では高減衰ゴム系積層ゴム(以下、HDR)を対象に、その終局 特性を予測する。FEM で積層ゴムの特性を予測する際には、特にゴ ムの材料モデルの適切な選定が重要となる。ゴムの材料モデルとし ては超弾性モデルが適用されることが多いが、HDR を含む積層ゴ ムの特性を高精度に予測可能な材料モデルが存在しないことが課題 であった。そこで過去筆者らは、HDR の水平 2 方向加力時の水平 特性を予測可能な材料モデルを提案し、その妥当性を検証した ${ }^{4)}$ 。 本弾塑性モデルは変形履歴積分型弾塑性モデルと呼ばれており、風 荷重のような一定方向加力下でのクリープ特性も予測が可能である 5)。また、本弾塑性モデルは時刻歴応答解析における履歴モデルとし

\footnotetext{
*1 ブリヂストン免制震開発部 博士(理学)

*2 ブリヂストン免制震開発部 Ph.D.
}

Bridgestone Corporation, Seismic Isolation and Vibration Control Products Development Dept., Dr.Sci.

Bridgestone Corporation, Seismic Isolation and Vibration Control Products Development Dept., Ph.D. 
ても提案されている6)。また筆者らは、天然ゴム系積層ゴムや鉛挿 入型積層ゴムを対象に、積層ゴム特有の引張大変形時のボイド生成 による引張剛性低下を再現できる材料モデルを提案し7)、その妥当 性を検証した 8), 9)。更に、天然ゴム系積層ゴムや鉛挿入型積層ゴム を対象に、水平大変形時のせん断破断ひずみや、引張大変形時の引 張破断ひずみを予測可能な解析手法を提案し、その妥当性を検証す るとともに 10)、様々な応用解析を実施した 2), 11), 12)。しかしながら、 HDR のせん断破断特性、引張破断特性、座屈特性を同時に予測可能 な材料モデルが未確立であることが大きな課題であった(その課題 の詳細は 2.2 節で述べる)。そこで本研究では、初めに「せん断破断」、

「引張破断」、「座屈」を同時に予測可能な HDR の材料モデルを提 案し ${ }^{13)}$ 、試験結果と比較することでその妥当性を検証する。続いて、 二次形状係数 $S_{2}$ に着目し、 $S_{2}$ が HDR の終局特性に与える影響を FEM で予測する。尚、天然ゴム系積層ゴムにおける「引張破断」の $S_{2}$ 依存性は筆者らによって既に報告されているが 14)、それを HDR に展開し、更に「せん断破断」と「座屈」も同時に予測する。

\section{FEMによる終局特性予測手法}

\section{1 終局特性予測手法の概要}

前述のとおり、本研究では HDR 向けに「せん断破断」、「引張破 断」、「座屈」の 3 つの終局特性に注目した終局特性の予測手法を提 案する。それぞれの予測手法を以下に示す。

$<$ 座屈 $>$

所定の鉛直荷重を与えた状態で、水平方向に単調加力する解析を 実施する。せん断応力-せん断ひずみ関係に負勾配が生じた瞬間のひ ずみを座屈ひずみと定義する。

<せん断破断、引張破断>

文献 10)にある筆者らが提案した手法に基づいてせん断破断ひず みと引張破断ひずみを予測する。文献 10)における破断ひずみ予測 手法の概要は以下のとおりである。

（1）解析前に予め破断指標と破断クライテリア值を適切に設定

（2）様々な面圧での水平加力解析、様々なオフセットせん断ひず みでのオフセット引張解析を実施

（3）各解析において、破断起点にある要素の破断指標がクライテ リア值に到達した瞬間の積層ゴムのせん断ひずみや引張ひずみ をせん断破断ひずみ・引張破断ひずみと定義

文献 10)では、破断指標として「最大主伸長比 $\lambda_{1}$ 」、「最大主伸長比 $\lambda_{1}$ と最小主伸長比 $\lambda_{3}$ の線形和 $\lambda_{1}+\alpha \lambda_{3}$ 」、「ひずみエネルギー」の 3 つ を提案している( $\alpha$ はゴム材料ごとに決まる定数である)。本研究では 最も予測精度が高いと考えられる最大主伸長比と最小主伸長比の線 形和 $\lambda_{1}+\alpha \lambda_{3}$ を破断指標として採用寸る。即ち、「せん断破断」と「引 張破断」を評価する解析においては、想定される破断起点要素にお ける $\lambda_{1}+\alpha \lambda_{3}$ があるクライテリア值 $B_{\mathrm{cr}}$ に達した瞬間の積層ゴム全体 の変形ひずみを破断ひずみとして算定する。

以上が、「せん断破断」「引張破断」「座屈」の予測手順であるが、 HDRに関しては、ゴムの持つ減衰の影響で水平 1 方向加力に対し、 水平 2 方向加力時にせん断破断ひずみが低下寸ることが知られてい る $\left.{ }^{15)}, 16\right) 。$ 従って、HDR のせん断破断ひずみの評価では、水平 2 方 向加力の下で評価する。「座屈」と「引張破断」も2 方向加力の影響 があると考えられるが、本研究では評価簡易化の目的のため、「座屈」
と「引張破断」に関しては、水平 1 方向加力で評価することとする。

\section{2 高減衰ゴム系積層ゴムの材料モデル}

本節では、「せん断破断」「「張破断」「座屈」の 3 つの終局特性 を同時に予測可能な HDR 向けの材料モデルを提案する。前節で述 べたように、過去、筆者らによって変形履歴積分型弾塑性モデルや、 剛性低下を考慮した弾性モデルが提案されている。前者は HDR を 対象に 2 方向加力含めた履歴特性を再現可能な弾塑性材料モデルで あり、後者は天然ゴム材料を主対象に引張加力時のボイド発生によ る剛性低下を表現できる材料モデルである。文献 10)にあるとおり、 後者のモデルは天然ゴム系積層ゴムや鈆抻入型積層ゴムの引張破断 までの引張大変形時の特性を高精度に予測可能である。HDR にお いて「せん断破断」「引張破断」、座屈」の 3 つの終局特性を同時 予測するには、上記 2 つの材料モデルを組合わせる必要があり、本 報告では HDR を対象に引張による剛性低下を表現できる変形履歴 積分型弾塑性モデルを提案する。しかしながら、両者を組み合わせ た材料モデルを単純に決定することはできない。その理由の詳細は 後述するが、塑性項の構成則を適切に設定する必要があり、HDR の 特性を高精度に再現可能な塑性項の材料モデルを検討する必要があ る。そこでまず、適切と考えられる材料モデル、即ち、引張による 剛性低下を表現できる変形履歴積分型弾塑性モデルを新たに提案す る。次に、試験結果と比較することでモデルの妥当性を検証する。 本研究で提案する高減衰ゴム用材料モデルを次式に示す。

$$
\boldsymbol{S}=2 \frac{\partial W_{\infty}}{\partial \boldsymbol{C}}+2 \frac{\partial W_{\mathrm{vol}}}{\partial \boldsymbol{C}}+2 \sum_{i=1}^{\mathrm{n}} g_{i} \int_{0}^{L} \frac{d}{d L^{\prime}}\left(\frac{\partial W_{0}}{\partial \boldsymbol{C}}\right) e^{-\left(L-L^{\prime}\right) / l_{i}} d L^{\prime}
$$

$$
\begin{aligned}
& L=\int_{0}^{t} \sqrt{\frac{2}{3} \boldsymbol{D}^{\prime}: \boldsymbol{D}^{\prime}} d t \\
& W_{\infty}=a\left(I_{1}-3\right)+b\left(I_{1}-3\right)^{3} \\
& W_{0}=\bar{I}_{1}-3 \\
& \left\{\begin{array}{lr}
W_{\mathrm{vol}}=\frac{1}{2} \kappa_{1}(J-1)^{2} & (J-1<0) \\
W_{\mathrm{vol}}=\frac{1}{2} \kappa_{2}(J-1)^{2} & (0 \leq J-1<\varepsilon) \\
W_{\mathrm{vol}}=\frac{1}{2} \kappa_{3}(J-1)^{2}+\varepsilon\left(\kappa_{2}-\kappa_{3}\right)(J-1)-\frac{1}{2}\left(\kappa_{2}-\kappa_{3}\right) \varepsilon^{2} & (\varepsilon \leq J-1)
\end{array}\right.
\end{aligned}
$$

$\boldsymbol{S}$ は第 2 Piola-Kirchhoff 応力テンソルを、C は右 Cauthy-Green テンソルを、D変形速度テンルの偏差成分を、 $I_{1} 、 \bar{I}_{1}$ はそれぞれ右 Cauthy-Green テンソルの第 1 不変量と第 1 低減不変量を、 $J$ は変 形勾配テンソルの Jacobian(即ち、体積変形率)を、 $L$ は状態変数で あり、変形開始時刻から現時刻までの相当ひずみ増分の累積值を表 す。 $a 、 b 、 \kappa_{1} 、 \kappa_{2} 、 \kappa_{3} 、 \varepsilon 、 g_{1} 、 \ldots 、 g_{\mathrm{n}} 、 l_{1} 、 \ldots 、 l_{\mathrm{n}}$ は材料パラメータで あり、 $\mathrm{n}$ は塑性項の数を表す。 $\mathrm{n}$ は通常 1 ～程度であり、 $\mathrm{n}$ が大き い程材料定数の数も増えモデルの精度が向上寸るが、材料定数の同 定が煩雑になる。 $W_{0}$ 及び $W_{\infty}$ は等容変形に関するひずみエネルギー 関数であり、 $W_{\mathrm{vol}}$ は体積変形に関するひずみエネルギー関数である。 一般に、微圧縮性を示すゴム材料の場合、等容変形成分のひずみ工 ネルギー関数 $W_{\infty}$ は、右 Cauchy-Green テンソルの低減不変量を用 いて記述される。しかしながら、文献 7)に示すように、等容変形成 
分のひずみエネルギー関数に低減不変量を用い、体積変形成分に式 （5）で示される剛性低下を考慮したひずみエネルギー関数を用いた 場合、オフセットせん断ひずみを与えて引張加力した時や水平方向 に大変形加力した時に、過度に引張剛性や水平剛性が低下寸る現象 が見られた。そのため、体積変形成分に剛性低下を考慮したひずみ エネルギー関数を用いる場合、等容変形成分のひずみエネルギー関 数は低減不変量 $\bar{I}_{1}$ ではなく、通常の不変量 $I_{1}$ を用いて記述した。同様 の問題が $W_{0}$ にも生じる可能性があり、 $W_{0}$ を通常の不変量と低減不 変量のどちらで記述した方が高減衰ゴム材料の特性を適切に表現で きるのか、明確ではない。しかしながら、 $W_{0}$ を通常の不変量を用い て下式(6)のように記述した場合、式(7)のように塑性項である式(1) の第 3 項中の偏微分が単位テンソル $\boldsymbol{I}$ となる。更にその単位テンソ ルを $L$ で微分すると塑性項が零テンソル $\boldsymbol{O}$ となり、塑性化しない問 題が生じる。一方で、式(4)のように低減不変量で $W_{0}$ を記述した場 合、式(8)のように式(1)中の第 3 項中の偏微分が単位テンソルとは ならず、 $L$ で微分しても塑性項が有限の值をとる。 $C^{-1}$ は右 CauchyGreen テンソルの逆テンソルである。即ち、 $W_{\infty}$ を通常の不変量で記 述し、 $W_{0}$ については低減不変量で記述するという特殊な HDR 向け の材料モデルを提案する。このような記述で高減衰モデルを適切に 表現できるかどうかについては、 3 章で検証する。 $W_{0}$ を $W_{\infty}$ のよう に高次の項でモデル化しても塑性項が $\boldsymbol{O}$ となる問題を解決できる が、本研究では式(1)〜 (5)を提案する。式(7)、(8)中のテンソルの微 分に関しては、例えば文献 17)を参照。尚、文献 13)で提案した材料 モデルと、本研究で提案した材料モデル式(1)〜(5)は関数形が以下の 2 点で異なる。1 点目は、文献 13)では $W_{\infty}$ を Yeoh モデルの 3 次の 項を無視した材料モデルとしたが、ゴムのハードニング特性をより 正確に表現できるよう、本研究では Yeoh モデルの 2 次の項を無視 したモデルとした。2 点目は、文献 13)では $W_{\mathrm{vol}}$ の引張領域の特性 をトリリニアでモデル化したが、バイリニアでも十分な精度がある ため、簡単化のためバイリニアとした。

$$
\begin{aligned}
& W_{0}^{*}=I_{1}-3 \\
& \frac{\partial W_{0}^{*}}{\partial \boldsymbol{C}}=\frac{\partial}{\partial \boldsymbol{C}}\left(I_{1}-3\right)=\boldsymbol{I} \\
& \frac{\partial W_{0}}{\partial \boldsymbol{C}}=\frac{\partial}{\partial \boldsymbol{C}}\left(\bar{I}_{1}-3\right)=J^{-2 / 3}\left(\boldsymbol{I}-\frac{1}{3} I_{1} \boldsymbol{C}^{-1}\right)
\end{aligned}
$$

\section{3. 高減衰ゴム材料モデルの妥当性検証}

2 章で提案した材料モデルを適用した FEM モデルを作成し、 HDR の水平 $1 、 2$ 方向加力試験及び引張試験との比較を行い、材料 モデルの妥当性を検証する。

\section{1 試験及び解析概要}

初めに比較対象の試験概要を説明する。試験体諸元を Table 1 に、 試験条件を Table 2-5 に示す。表中の $\sigma_{\mathrm{s}}$ は基準面圧を表す。試験に 用いた HDR は、等価水平剛性 $0.620 \mathrm{MPa}$ 、等価粘性減衰定数 0.240 の特性を有するものとした(以下、HDR-G0.6)。加力条件は、Table $2-5$ からわかるように、水平 1 方向加力、水平 2 方向加力、引張加 力に加えて、鉛直剛性を把握する目的で鉛直圧縮加力も実施した。 Table 2 からわかるように、水平 1 方向加力については、せん断ひ ずみ依存性評価のためにせん断ひずみを徐々に大きくする漸増載荷
と、座屈・せん断破断特性評価のための単調載荷の 2 パターン解析 した。Table 3 からわかるように、水平 2 方向加力では、長軸方向 せん断ひずみ 2 、短軸方向せん断ひずみ 1 の 8 の字加力を実施した。 試験における水平 1 方向加力の漸増載荷と 2 方向水平加力は縮小試 験体を用いている。これは、試験機能力の都合であり、動的試験や 2 方向試験が実大試験体での実施が困難であったためである。一方、 座屈特性を把握する水平 1 万向加力試験や引張試験では実大試験体 を用いた。ただし、試験機能力の理由により加力条件は全て静的な ものである。Table 4 からわかるように、引張試験ではオフセット せん断ひずみ 1 の下、鉛直方向に単調に引張変形を与えた。

試験と比較する為の FEM 解析モデルを Fig. 1 に示す。Fig. 1 か らわかるように、解析条件によってモデル化の内容が異なる。水平 加力が水平 2 方向ではなく水平 1 方向のみの場合は対称性を考慮し た $1 / 2$ モデルでモデル化し、フランジの厚みが解析結果に影響を与 えると考えられる No.5 の引張加力ではフランジや取付ボルトもモ デル化している。フランジの中央部厚みは $32 \mathrm{~mm}$ 、ボルト締結する 端部厚みは $24 \mathrm{~mm}$ 、フランジ径は $1150 \mathrm{~mm}$ 、取付ボルト本数は 12 である。また Fig. 1 にも示したように、引張試験におけるフランジ の厚みの影響を評価する目的で、フランジ・ボルトをモデル化しな い場合(フランジを剛体とみなした場合)の解析も実施している。各 試験体は被覆ゴムで積層部が覆われているが、解析結果に与える影 響は小さいと考えモデル化を省略している。使用要素は、ゴムは六 面体 8 節点要素、鋼材類は六面体 8 節点一様低減積分要素とした。 水平方向要素分割数は $1 / 2$ モデルで $100 \sim 320$ 程度であり、座屈や 引張解析では分割数を多めとした。鉛直方向は、文献 10) と同様に ゴム・鋼板ともに分割していない。No.7 のモデルに関しては、破断 ひずみを予測することを目的に、破断指標のクライテリア值を決定 するための微小要素が破断起点に設けられている 10)。その為、No.7 のみ水平方向の分割数が多い。詳細は 4.1 節で述べる。境界条件に 関しては、フランジ・ボルトをモデル化するかどうかで異なる。フ ランジ・ボルトをモデル化しない場合は、ゴム最下面の境界条件は 完全固定の変位 0 とした。ゴム最上面の境界条件は、全節点を水平 2 方向と鉛直方向の 3 自由度を持つコントロールノードとタイイン グし、コントロールノードに所定の荷重と変位を与えた。最上面は 回転も拘束している。フランジ・ボルトをモデル化した場合は、ゴ ムではなくボルト最下面を完全固定、ボルト最上面をコントロール ノードでタイイングした。フランジ・ボルトをモデル化した場合の 各部材間の境界条件は Table 6 に示す。内部ゴムの材料定数は試験 結果に合うように決定し、塑性項の数は $\mathrm{n}=2$ とした。 $a 、 b 、 g_{1} 、 g_{2}$ 、 $l_{1} 、 l_{2}$ は高減衰積層ゴムの水平 1 方向加力試験から得られたせん断応 力ーせん断ひずみ曲線に合うように(Table 2 の Test No.: U-1、U-4)、 $\kappa_{2} 、 \kappa_{3} 、 \varepsilon$ はオフセットせん断ひずみ 1 の引張試験から得られた鉛直 応力-鉛直ひずみ曲線に合うように(Table 4 の Test No.: T-1)、 $\kappa_{1}$ は 鉛直加力時の鉛直剛性の設計值に合うように(Table 5 の Test No.: $\mathrm{V}-1$ )決定した。 $\kappa_{1}$ のみ実験結果ではなく設計值に合うように決定し た。内部ゴムの材料定数を表 Table 7 に、内部鋼板、フランジ、ボ ルトの材料定数を Table 8 に示寸。尚、Test No.U-1、V-1 は 3 サイ クル加力しているが、解析は繰返しによる特性変化は小さく、計算 効率も考慮し 1 サイクルのみとした。 
Table 1 Specifications of test specimens

\begin{tabular}{|c|c|c|c|c|}
\hline Specimen No. & $\begin{array}{c}\text { No.1 } \\
\text { No.2 }\end{array}$ & $\begin{array}{c}\text { No.3 } \\
\text { No.4 }\end{array}$ & $\begin{array}{c}\text { No.5 } \\
\text { No.6 }\end{array}$ & No.7 \\
\hline \hline Outer diameter $(\mathrm{mm})$ & 158 & 600 & 800 & 700 \\
\hline Rubber thickness $(\mathrm{mm})$ & 1.26 & 4.0 & 5.4 & 4.7 \\
\hline Number of layer & 31 & 50 & 37 & 18 \\
\hline First shape factor $S_{1}$ & 31.3 & 36.6 & 36.1 & 36.4 \\
\hline Second shape factor $S_{2}$ & 4.05 & 3.0 & 4.0 & 8.3 \\
\hline Shear modulus $(\mathrm{MPa})$ & 0.620 & 0.620 & 0.620 & 0.620 \\
\hline $\begin{array}{c}\text { Equivalent shear stiffness } \\
(\mathrm{kN} / \mathrm{mm})\end{array}$ & 0.311 & 0.876 & 1.56 & 0.746 \\
\hline Equivalent damping ratio & 0.240 & 0.240 & 0.240 & 0.240 \\
\hline Vertical stiffness $(\mathrm{kN} / \mathrm{mm})$ & 684 & 1970 & 3510 & 2290 \\
\hline
\end{tabular}

Table 2 Uni-directional horizontal loading conditions

\begin{tabular}{|c|c|c|c|c|}
\hline Specimen No. & No.1 & No.3 & No.4 & No.7 \\
\hline Test No. & U-1 & U-2 & U-3 & U-4 \\
\hline \hline $\begin{array}{c}\text { Horizontal loading } \\
\text { condition }\end{array}$ & $\begin{array}{c}\text { Gradually shear } \\
\text { strain increase } \\
\text { loading }\end{array}$ & \multicolumn{3}{|c|}{ Monotonic loading } \\
\hline Shear strain & $0.5,1,1.5,2,2.5$ & \multicolumn{3}{|c|}{-} \\
\hline Loading frequency & $0.1 \mathrm{~Hz}$ & \multicolumn{3}{|c|}{-} \\
\hline $\begin{array}{c}\text { Number of cycles } \\
\text { for each strain }\end{array}$ & 3 & & - & \\
\hline $\begin{array}{c}\text { Compressive } \\
\text { stress }(\mathrm{MPa})\end{array}$ & $\begin{array}{c}10.7 \\
\left(\sigma_{\mathrm{s}}\right)\end{array}$ & $\begin{array}{c}\mid c \\
\left(\sigma_{\mathrm{s}}\right)\end{array}$ & $\begin{array}{c}13.2 \\
\left(2 \sigma_{\mathrm{s}}\right)\end{array}$ & $\begin{array}{c}15.0 \\
\left(\sigma_{\mathrm{s}}\right)\end{array}$ \\
\hline
\end{tabular}

Table 3 Bi-directional horizontal loading condition

\begin{tabular}{|c|c|}
\hline Specimen No. & No.2 \\
\hline Test No. & B-1 \\
\hline $\begin{array}{c}\text { Horizontal loading } \\
\text { condition }\end{array}$ & $\begin{array}{c}\text { Orbit: Shape of "8" (See Fig. 2) } \\
\text {-direction: Sin wave, 1cycle, } 0.01 \mathrm{~Hz} \\
\mathrm{y} \text {-direction: Sin wave, 2cycles, } 0.02 \mathrm{~Hz}\end{array}$ \\
\hline $\begin{array}{c}\text { Compressive stress } \\
(\mathrm{MPa})\end{array}$ & $10.7\left(\sigma_{\mathrm{s}}\right)$ \\
\hline
\end{tabular}

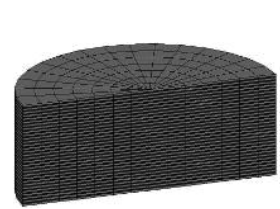

No.1 ( $(158)$ Rigid surface

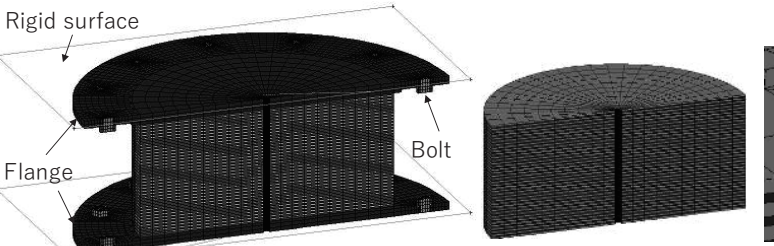

No.5 with flange $(\varphi 800)$
No.5 without flange and No.6 ( $(980)$

Fig. 1 Analysis models
Table 4 Tensile loading condition

\begin{tabular}{|c|c|}
\hline Specimen No. & No.5 \\
\hline Test No. & $\mathrm{T}-1$ \\
\hline \hline Tensile loading condition & $\begin{array}{c}\text { Monotonic tensile loading } \\
\text { under given offset shear strain }\end{array}$ \\
\hline Offset shear strain & 1 \\
\hline
\end{tabular}

Table 5 Vertical compressive loading condition

\begin{tabular}{|c|c|}
\hline Specimen No. & No.6 \\
\hline Test No. & $\mathrm{V}-1$ \\
\hline \hline $\begin{array}{c}\text { Vertical compressive loading } \\
\text { condition }(\mathrm{MPa})\end{array}$ & $12.0 \pm 3.6\left(\sigma_{\mathrm{s}} \pm 30 \%\right)$ \\
\hline Number of cycles & 3 \\
\hline
\end{tabular}

Table 6 Boundary conditions between each material

\begin{tabular}{|c|c|}
\hline Flange - Base Plate & Contact (Friction coefficient: 0.4) \\
\hline Bolt - Flange & Contact (Friction coefficient: 0.4) \\
\hline Laminated layer - Flange & Glue contact \\
\hline Other & Node share \\
\hline
\end{tabular}

Table 7 Material properties for rubber

\begin{tabular}{|c|c|c|c|c|}
\hline $\begin{array}{c}a \\
(\mathrm{MPa})\end{array}$ & $\begin{array}{c}b \\
(\mathrm{MPa})\end{array}$ & $\begin{array}{c}\kappa_{1} \\
(\mathrm{MPa})\end{array}$ & $\begin{array}{c}\kappa_{2} \\
(\mathrm{MPa})\end{array}$ & $\begin{array}{c}\kappa_{3} \\
(\mathrm{MPa})\end{array}$ \\
\hline \hline 0.082 & 0.00006 & 1450 & 100 & -0.15 \\
\hline
\end{tabular}

\begin{tabular}{|c|c|c|c|c|}
\hline$\varepsilon$ & $\begin{array}{c}g_{1} \\
(\mathrm{MPa})\end{array}$ & $\begin{array}{c}g_{2} \\
(\mathrm{MPa})\end{array}$ & $l_{1}$ & $l_{2}$ \\
\hline \hline 0.0175 & 0.44 & 0.07 & 0.15 & 23 \\
\hline
\end{tabular}

Table 8 Material properties for insert plate, flange and bolt

\begin{tabular}{|c|c|c|c|c|}
\hline & $\begin{array}{c}\text { Yang's } \\
\text { modulus } \\
(\mathrm{GPa})\end{array}$ & $\begin{array}{c}\text { Poisson } \\
\text { ratio }\end{array}$ & $\begin{array}{c}\text { Yielding } \\
\text { stress } \\
(\mathrm{MPa})\end{array}$ & $\begin{array}{c}\text { Post yielding } \\
\text { Modulus } \\
(\mathrm{MPa})\end{array}$ \\
\hline \hline Insert plate & 205 & 0.3 & 235 & 0 \\
\hline Flange & 205 & 0.3 & 235 & 0 \\
\hline Bolt & 205 & 0.3 & - & - \\
\hline
\end{tabular}

Small element to

evaluate principal stretch

ratio averaged by volume

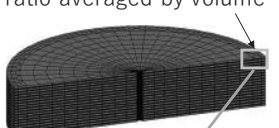

No.7 ( $\varphi 700)$

Zoom in

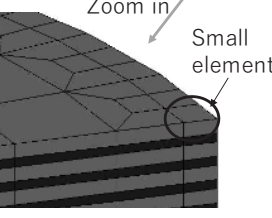

element ,

\footnotetext{
Fig.
}

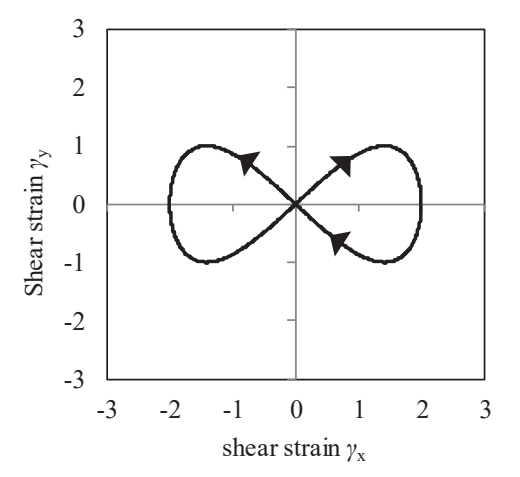

g. 2 Orbit of bi-directional 8-shape loading

\section{2 解析結果}

解析結果と試験結果の比較を Fig. 3 に示す。Fig. 3(a)〜 (h) は応力 一ひずみ関係であり、Fig. 3(i)のみ荷重-変位関係である。黒線が試験 結果であり、灰色線が解析結果であるが、Fig. 3(i)の鉛直加力のみ試 験ではなく鉛直剛性の設計值と比較した。Fig. 3(a)より、水平 1 方 向加力ではせん断ひずみ 50〜 $250 \%$ の広い領域において、せん断応
力ーせん断ひずみ曲線が試験結果と解析結果でよく一致しているこ とがわかる。Fig. 3(b)より、破断に至るせん断ひずみ 5.72 を超える 領域まで試験結果と解析結果が概ね一致していることがわかる。 Fig. 3(c)より、試験と解析で座屈ひずみが若干解析の方が大きく評 価されているが、基準面圧・倍面圧共に概初結果が一致しているこ とがわかる。Fig. 3(d)より、水平 2 方向加力時の HDR の複雑な振 
舞いも高精度に再現できていることがわかる。Fig. 3(e)、(f)より、 オフセットせん断ひずみ $100 \%$ の張ひずみ $25 \%$ までの領域ではあ るが、試験結果と解析結果がよく一致していることがわかる。試験 機能力等の関係で HDR の引張試験に関するデータが不足している が、文献 10)にある鈆挿入型積層ゴムの各オフセットせん断ひずみ での破断までの引張応力-引張ひずみ特性とは概ね一致した傾向が 見られる。HDR と鉛挿入型積層ゴムの引張特性が同じ傾向を示す という知見はないが、同じゴムということを考えれば、他のオフセ ットせん断ひずみや大変引張形領域での特性も概ね一致することが 予想される。Fig. 3(g)、(h)には、フランジをモデル化した場合とし ない場合での解析結果の比較を示した。特に小ひずみ領域で、フラ ンジ厚みは引張特性に大きく影響することがわかる。Fig. 3(i)には、 試験と解析の比較に加え、設計值もプロットした。試験・解析・設 計值ともに鉛直剛性を表す傾きは良く一致していることがわかる。 ただし鉛直変形量は解析・設計值に比べ試験の方が大きく、右側に シフトしている。これは、積層ゴムの鉛直変形量が $2 、 3 \mathrm{~mm}$ と小さ
く、試験でのフランジや面盤等の変形が影響していると推測される。 以上、材料定数を適切に決定することで、式(1)〜(5)の材料モデル で HDR の水平 2 方向加力や大変形含む水平加力時の特性、鉛直圧 縮時の特性、鉛直引張時の特性を高精度に再現できることがわかる。 試験結果に合うように材料定数を決定したため、試験結果と解析結 果が一致するのは当然とも言えるが、既存の材料モデルでは試験と 解析が一致する材料定数が存在しないこと自体が課題であり、本材 料モデルの提案は大いに意味がある。また、材料モデルの同定に用 いていない試験データとの比較(Fig. 3(c)、(d))でもよい一致が見ら れ、提案した材料モデルが妥当であることがわかる。FEM 解析結果 において、文献 9)で見られたように $W_{0}$ を低減不変量で定義した際 の、オフセットせん断ひずみを与えて引張加力した時や大変形加力 した時に、過度に剛性が低下寸る現象も見られなかった。即ち、式 (1) (5) で与えられる本研究で提案した HDR の材料モデルで、せん 断破断、引張破断、座屈の終局特性を統一的に予測が可能であり、 高減衰ゴムの特性を高い精度で表現できると考えられる。

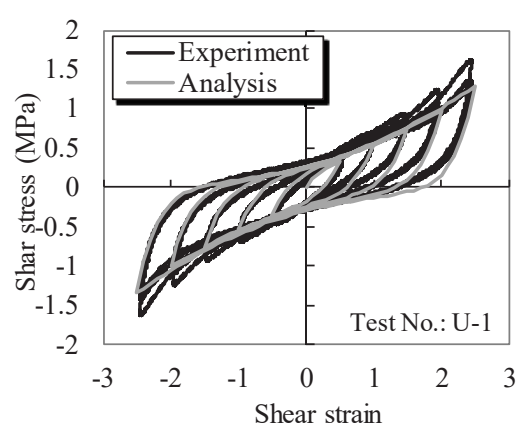

(a) Uni-directional horizontal loading

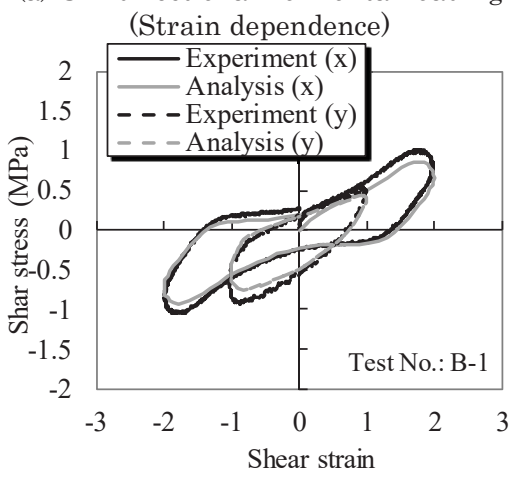

(d) Bi-directional horizontal loading

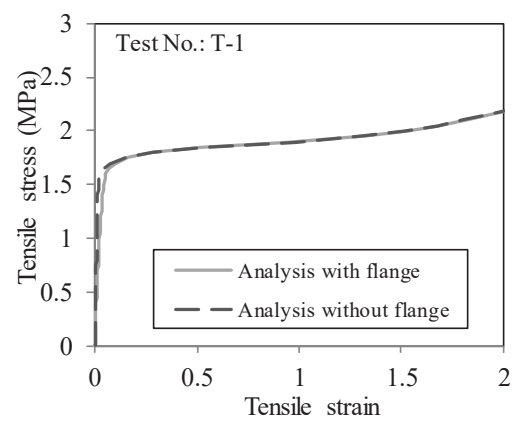

(g) Tensile loading

(Flange thickness dependence) (Large range of tensile strain)

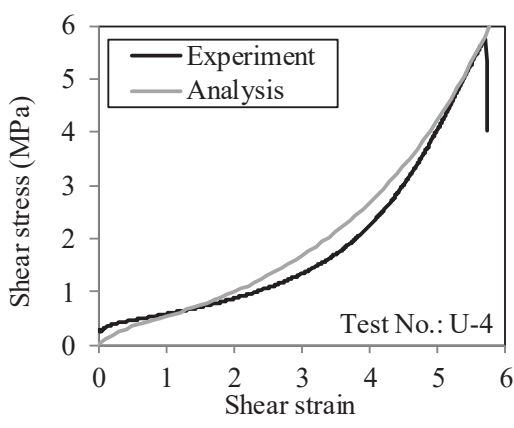

(b) Uni-directional horizontal loading (Comparison with break test)

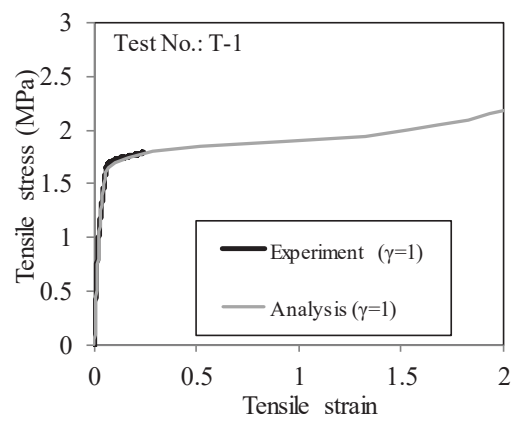

(e) Tensile loading (Large range of tensile strain)

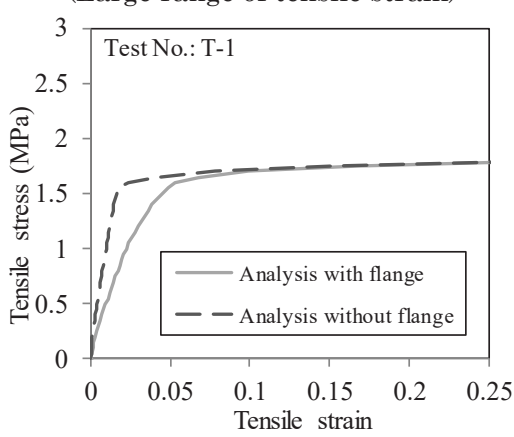

(h) Tensile loading

(Flange thickness dependence)

(Small range of tensile strain)

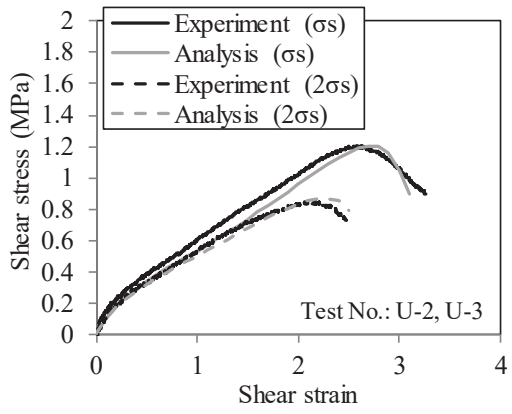

(c) Uni-directional horizontal loading (Comparison with buckling test)

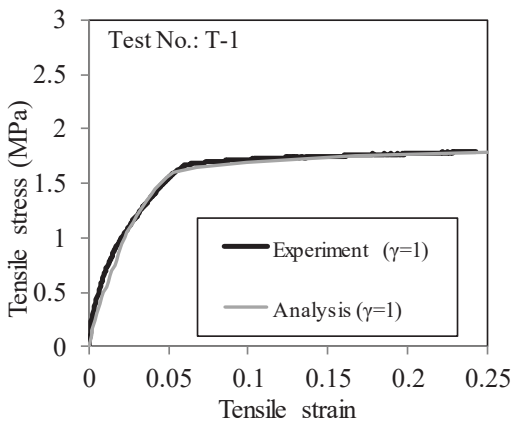

(f) Tensile loading

(Small range of tensile strain)

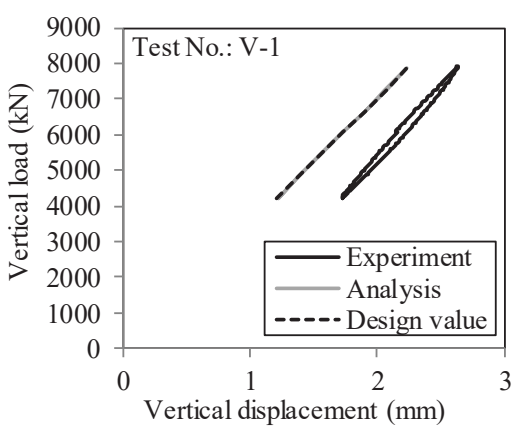

(i) Vertical compressive loading

Fig. 3 Analysis results and comparison with test results 


\section{4. 二次形状係数が終局特性に与える影響解析}

\section{1 解析概要}

既往の研究 10)では、鋁挿入型積層ゴムを対象に、様々な要因が 引張破断ひずみに与える影響を解析した。製造ばらつきの影響とし て「積層ゴムの水平剛性ばらつき」、積層ゴムの引張剛性ばらつき」、 「ゴム自体の破断クライテリアばらつき」を評価し、構造の影響と して「内部鋼板と内部ゴムの厚みの比」、鉛プラグ有無」、鉛プラ グ配置」が引張破断特性に与える影響を評価した。本研究では、HDR を対象に鈆挿入型積層ゴムでは影響評価を実施していない「二次形 状係数 $S_{2}$ 」が終局特性に与える影響を評価する。文献 10)において は、「引張破断」のみの評価であったが、本研究では「引張破断」に 加え、「せん断破断」と「座屈」も予測する。対象の積層ゴムは 3 章 で評価した HDR-G0.6 と同じと寸る。1 章で述べたとおり、破断指 標は $\lambda_{1}+\alpha \lambda_{3}$ とするが、そのクライテリア值 $B_{\mathrm{cr}}$ を事前に設定する必 要がある。しかしながら、HDR-G0.6については引張破断試験の実 績がなく、せん断破断試験のみである。そこで、水平 1 方向破断試 験のみからクライテリア值を決定する。ここで $\alpha$ も決定する必要が あるが、破断試験データの不足から、 $\alpha$ は文献 10) と同じと仮定して せん断破断及び引張破断予測解析を実施した。文献 10)では具体的 なの值を省略しているが、 $\alpha=1.045$ である。水平 1 方向破断試験は、

Table 2 及び Fig. 3(b)に示したゴム外径 $\varphi 700$ 、二次形状係数 $S_{2}=8.3$

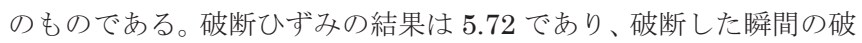
断起点における破断指標 $\lambda_{1}+\alpha \lambda_{3}$ の值は 6.223 であった。よって、 6.223 をそのままクライテリア值とする。

\section{2 解析モデル}

解析モデルの諸元を Table 9 に示寸。Table 9 からわかるように、 ゴム外径 $\phi 1000 、 S_{1}=35.2$ の積層ゴムを対象に、二次形状係数 $S_{2}$ の 依存性を評価する。 $S_{2}$ をパラメータにする場合、ゴム総厚さ一定で ゴム断面積を変化させる方法と、ゴム断面積を一定としてゴム総厚 さを変化させる方法があり、今回は後者としたが本質的には同じで ある。解析モデルを Fig. 4 に示す。今回はフランジ厚みの影響を排 除寸る目的で、フランジはモデル化を省略した。即ちフランジは十 分厚く、剛体とみなせると仮定した。上述のとおり、本研究では「せ 几断破断」、「引張破断」、「座屈」の 3 つの終局特性の $S_{2}$ 依存性を予 測する。「引張破断」、「座屈」は水平 1 方向加力で、「せん断破断」 は水平 2 方向加力時で終局特性を予測する。Fig. 4 からわかるよう に、水平 1 方向加力と引張加力における破断起点は固定されており、 灰色の四角形で囲まれた位置の要素である。一方、水平 2 方向加力 では、「水平加力によるせん断ひずみ」と「ねじれによるせん断ひず み」の和が最大となる点が破断起点となるが、その破断起点がどこ になるかを事前に予測することが難しい。そのため、各解析ステッ プでの破断指標の值が最大となる要素を都度検出する。終局特性予 測手法は 2.1 節で述べたとおりである。

\section{3 解析ケース・解析条件}

それぞれの終局特性把握解析における解析条件を Table 10-12 に 示す。Table 10 に示した水平 1 方向加力で座屈ひずみを、Table 11 に示した水平 2 方向加力でせん断破断ひずみを、Table 12 に示した 引張加力で引張破断ひずみを評価する。水平 2 方向加力は長軸方向
と短軸方向のせん断ひずみの比が 2:1 の棈円軌道であり、破断する まで徐々にせん断ひずみを大きくする。水平加力における面圧は 0 、 $15 、 30 \mathrm{MPa}$ の 3 水準である(水平 2 方向加力は $15 、 30 \mathrm{MPa}$ の 2 水 準のみ)。 $S_{2}=3.0$ の基準面圧は $6.6 \mathrm{MPa}$ であり、それに対しては非常 に高い面圧であるが、 $S_{2}$ 依存性を調べることが目的のため、面圧は そろえた。

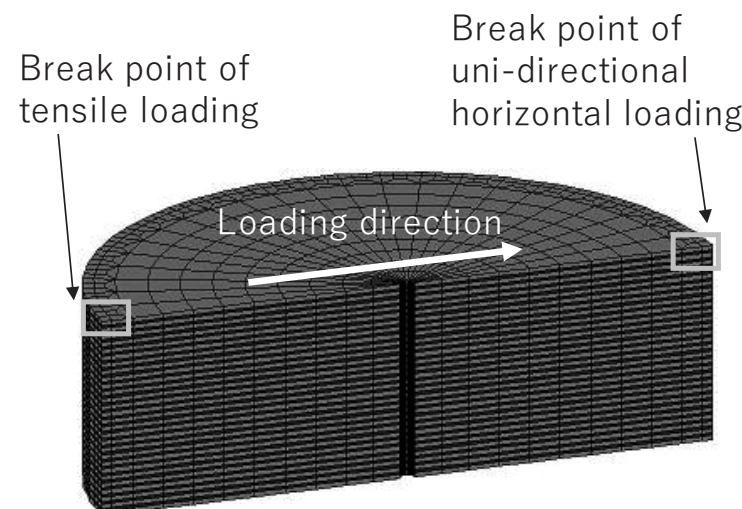

Analysis model for uni-directional horizontal and tensile loading

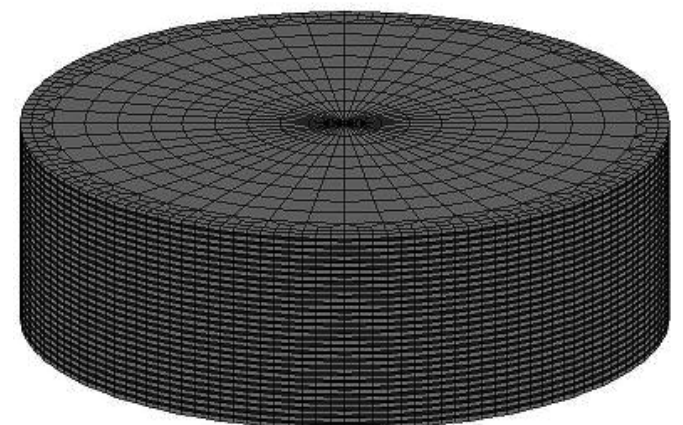

Analysis model for bi-directional horizontal loading

Fig. 4 Analysis model

Table 9 Specifications of analysis model

\begin{tabular}{|c|c|c|c|}
\hline Model Name & $\mathrm{S}-3$ & $\mathrm{~S}-5$ & $\mathrm{~S}-8$ \\
\hline Outer diameter $(\mathrm{mm})$ & \multicolumn{3}{|c|}{1000} \\
\hline Inner diameter $(\mathrm{mm})$ & \multicolumn{3}{|c|}{25} \\
\hline Rubber thickness $(\mathrm{mm})$ & \multicolumn{3}{|c|}{7.1} \\
\hline Number of layer & 47 & 28 & 17 \\
\hline Total rubber thickness $(\mathrm{mm})$ & 333.7 & 198.8 & 120.7 \\
\hline Insert plate thickness $(\mathrm{mm})$ & \multicolumn{3}{|c|}{4.4} \\
\hline First shape factor $S_{1}$ & \multicolumn{3}{|c|}{35.2} \\
\hline Second shape factor $S_{2}$ & 3.0 & 5.0 & 8.3 \\
\hline Shear modulus (MPa) & \multicolumn{3}{|c|}{0.620} \\
\hline $\begin{array}{l}\text { Equivalent shear stiffness } \\
(\mathrm{kN} / \mathrm{mm})\end{array}$ & 1.46 & 2.45 & 4.03 \\
\hline Equivalent damping ratio & \multicolumn{3}{|c|}{0.240} \\
\hline Vertical stiffness $(\mathrm{kN} / \mathrm{mm})$ & 3270 & 5490 & 9040 \\
\hline Nominal stress $\sigma_{\mathrm{s}}(\mathrm{MPa})$ & 6.6 & 15.0 & 15.0 \\
\hline
\end{tabular}




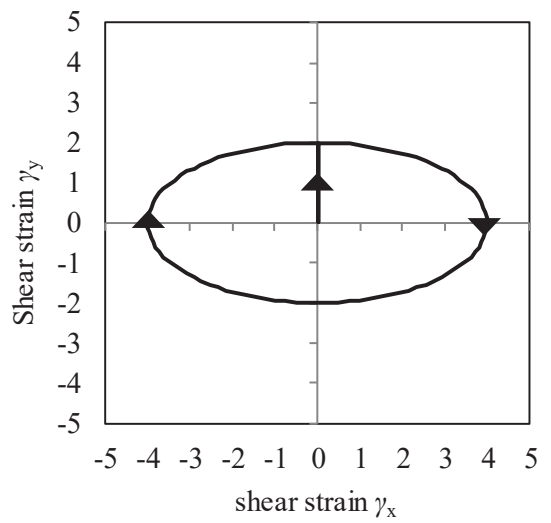

Fig. 5 Example of bi-directional loading orbit $\left(\gamma_{x}, \gamma_{y}\right)=(4,2)$

Table 10 Uni-directional horizontal loading conditions

\begin{tabular}{|c|c|c|c|}
\hline Analysis No. & U-A & U-B & U-C \\
\hline \hline Horizontal loading condition & \multicolumn{3}{|c|}{ Monotonic loading } \\
\hline Compressive stress $(\mathrm{MPa})$ & 0 & 15 & 30 \\
\hline
\end{tabular}

Table $11 \mathrm{Bi}$-directional horizontal loading conditions

\begin{tabular}{|c|c|c|}
\hline Analysis No. & B-A & B-B \\
\hline \hline $\begin{array}{c}\text { Horizontal loading } \\
\text { condition }\end{array}$ & Ellipse orbit loading (See Fig. 5) \\
\hline Shear strain\% & $\begin{array}{c}\left(\gamma_{\mathrm{x}}, \gamma_{\mathrm{y}}\right):(3.6,1.8),(3.8,1.9),(4.0,2.0), \ldots \\
\text { Shear strain gradually increases until } \\
\text { break occurs }\end{array}$ \\
\hline $\begin{array}{c}\text { Compressive stress } \\
(\mathrm{MPa})\end{array}$ & 15 & 30 \\
\hline
\end{tabular}

※ 1 cycle for each loading condition

Table 12 Tensile loading conditions

\begin{tabular}{|c|c|c|c|c|c|}
\hline Analysis No. & T-A & T-B & T-C & T-D & T-E \\
\hline \hline $\begin{array}{c}\text { Tensile loading } \\
\text { condition }\end{array}$ & \multicolumn{5}{|c|}{$\begin{array}{c}\text { Monotonic tensile loading under } \\
\text { given offset shear strain }\end{array}$} \\
\hline Offset shear strain & 0 & 1 & 2 & 3 & 4 \\
\hline
\end{tabular}

\section{4 解析結果}

$S_{2}=3.0 、 5.0 、 8.3$ の 3 水準で $S_{2}$ の影響を評価した結果を以下に示 す。水平 1 方向加力及び水平 2 方向加力におけるせん断応力-せん 断ひずみ関係の結果をそれぞれ Fig. 6、7 に示す。S2=3.0の面圧 15 、 $30 \mathrm{MPa}$ と $S_{2}=5.0$ の面圧 $30 \mathrm{MPa}$ の水平 2 方向加力では座屈により 解析が不安定化し、破断に至るまでの解が得られなかったため、結 果は省略している。○は破断点を、 $\triangle$ は座屈点を表す。水平 2 方向 加力における破断点は、棈円軌道最初の $1 / 2$ サイクルのうち破断起 点の破断指標が最大となった瞬間である。自明の結果ではあるが、 面圧が破断ひずみに与える影響は小さいが、座屈ひずみが面圧に大 きく依存することがわかる。またこれも自明の結果であるが、Fig. 6、7 からわかるように、水平加力においては $S_{2}$ が大きいと破断が 支配的であり、 $S_{2}$ が小さいと座屈が支配的となる。水平 2 方向加力 解析において、 $S_{2}=5.0$ は長軸方向せん断ひずみ 3.8 で、 $S_{2}=8.3$ では 長軸方向せん断ひずみ 4.4 で破断を生じた。面圧 $0 \mathrm{MPa}$ の水平 1 方 向加力では、破断ひずみは $S_{2}$ にほとんど依存しないが、水平 2 方向 加力では $S_{2}$ が小さい程破断ひずみが低下寸ることがわかる。

引張加力における引張応力-引張ひずみ関係の結果を Fig. 8、9 に
示す。Fig. 8 は大ひずみ領域、Fig. 9 は小ひずみ領域である。Fig. 8、9 からわかるように、オフセットせん断ひずみ 0 の場合は変形が 一様であるため、 $S_{2}$ の違いによる差はない。しかしながら、オフセ ットせん断ひずみが大きくなると、 $S_{2}$ やオフセットせん断ひずみに より、引張応力-引張ひずみ曲線の振舞が複雑に変化するが、概ね才 フセットせん断ひずみが小さい程引張剛性が低下寸ることがわかる。 縦軸に面圧を、縦軸にせん断破断ひずみ及び座屈ひずみをプロッ 卜した結果を Fig. 10 に示す。Fig. 10 におけるせん断破断ひずみは 2 方向加力における破断ひずみであり、破断が最初に生じた楕円加 力における長軸方向せん断ひずみである。座屈よりせん断破断が先 行(即ちせん断破断ひずみ>座屈ひずみ)し、座屈が得られなかったケ ースではせん断破断ひずみのみ示した。その逆も同じである。また、 縦軸に引張破断ひずみを、横軸にオフセットせん断ひずみをプロッ トした結果を Fig. 11 に示す。縦軸に破断ひずみではなく破断応力 をプロットした図も Fig. 11 (b)に示した。Fig. 11 において、引張ひ ずみ及び引張応力が 0 である点がプロットされているが、これは面 圧 $0 \mathrm{MPa}$ での水平 1 方向加力における破断ひずみを横軸上にプロッ トしたものである。Fig. 10、11より、S 2 の違いによる終局特性の違 いを一目で確認することができる。Fig. 11 からわかるように、オフ セットせん断ひずみ 0 と 1 で引張破断ひずみが大きく低下してい る。また、引張破断特性は $S_{2}$ が小さい程低下寸る。特にオフセット せん断ひずみ 1 では、破断ひずみが $S_{2}=3.0 、 5.0 、 8.3$ それぞれで $0.42 、 0.75 、 1.32$ であり、 $S_{2}$ により破断性能が大きく変動すること がわかる。 $S_{2}=3.0$ ではオフセットせん断ひずみ $2 \sim 4$ の領域におい て、オフセットせん断ひずみが大きい程破断ひずみ大きくなる現象 が見られた。破断起点は、引張力によるモーメントと水平力による モーメントのどちらが大きいかで破断起点が決まり、オフセットを 与えた引張破断では引張力によるモーメントが大きく、破断起点は Fig. 4 モデル図の左上か右下となる。しかしながら、オフセット変 形が大きい程水平力によるモーメントが大きくなり、水平力による モーメントを打ち消寸までに大きな引張変形を生じる必要があるか らである。ただし、特に $S_{2}=3.0$ の場合においては、オフセットせん 断ひずみ 3 以上では座屈が支配的であり、荷重支持能力を㶾失して いる領域である。従って、 $S_{2}=3.0$ のオフセットせん断ひずみ 3 以上 の領域を無視すれば、 $S_{2}$ が小さい程引張破断ひずみは低下するとい える。

$S_{2}$ が小さい程破断ひずみが小さくなる原因を示すため、Fig. 12 に オフセットせん断ひずみ 1 の引張加力で、引張ひずみが 1 になった 瞬間の最大主ひずみ(Green-Lagrange ひずみ)コンターを示す。Fig. 12 より、同じひずみ状態であっても、 $S_{2}$ が小さい程破断起点におけ る局部的なひずみが大きくなっていることがわかる。これにより、 $S_{2}$ が小さい程破断ひずみや破断応力が低下寸ると考えられる。

Fig. 13 には、 $S_{2}=8.3$ の水平 2 方向加力において楕円加力最初の $1 / 2$ サイクルで、破断起点の破断指標が最大となった瞬間の最大主 ひずみ(Green-Lagrange ひずみ)コンターを示す。加力直行方向でひ ずみが最大となり、その点が破断起点となると予測される。

以上、FEM による終局特性の予測解析を実施したが、終局特性は 定性的評価だけでなく定量的評価が重要となる。定量的にも試験結 果と解析結果が高精度に一致し、解析による定量的評価が可能かど うかの検証は今後の課題である。 


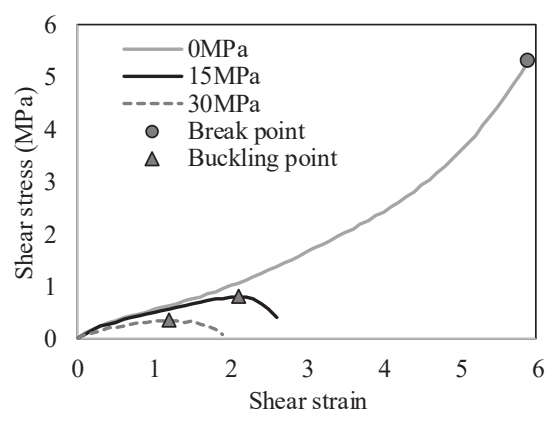

(a) $S_{2}=3.0$

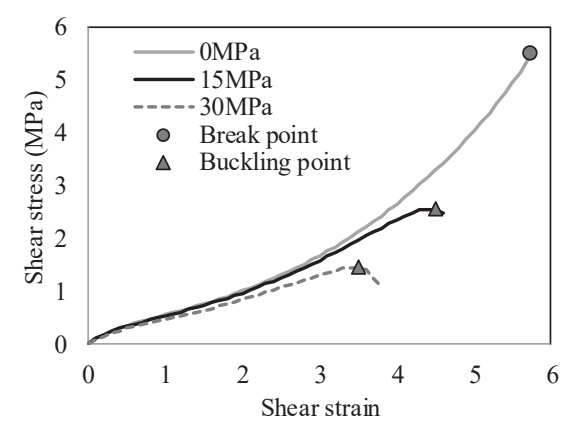

(b) $S_{2}=5.0$

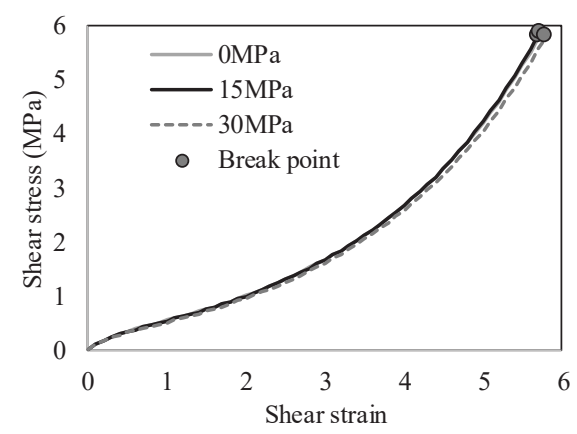

(c) $S_{2}=8.3$

Fig. 6 Shear stress - shear strain relationship (Uni-directional loading)

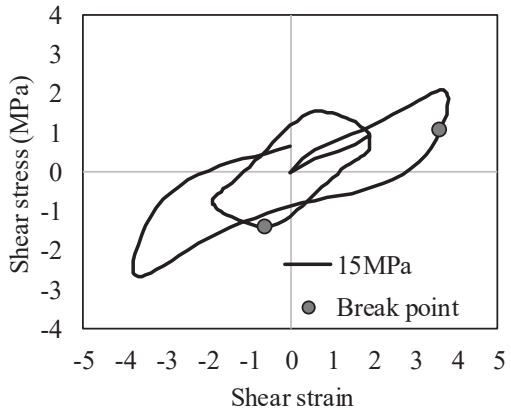

(a) $S_{2}=5.0$

Shear strain of major axis: 3.8

Shear strain of minor axis: 1.9

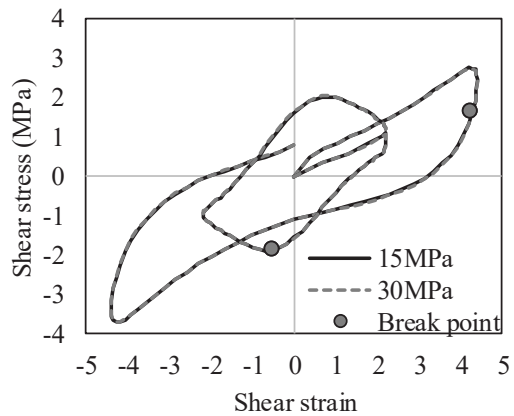

(b) $S_{2}=8.3$

Shear strain of major axis: 4.4

Shear strain of minor axis: 2.2

Fig. 7 Shear stress - shear strain relationship (Bi-directional loading)

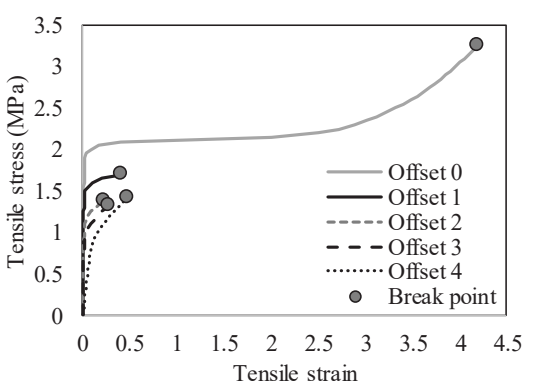

(a) $S_{2}=3.0$

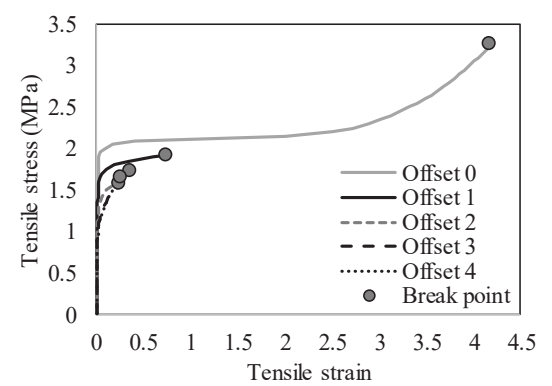

(b) $S_{2}=5.0$

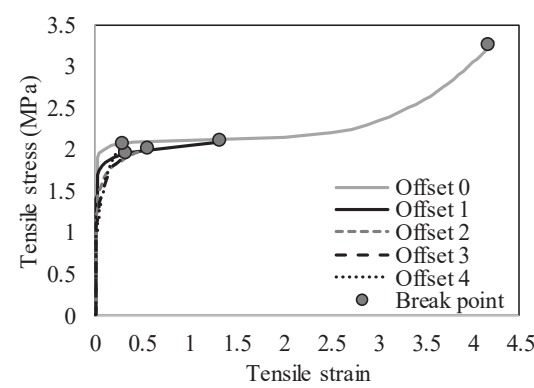

(c) $S_{2}=8.3$

Fig. 8 Tensile stress - tensile strain relationship (Large range of tensile strain)

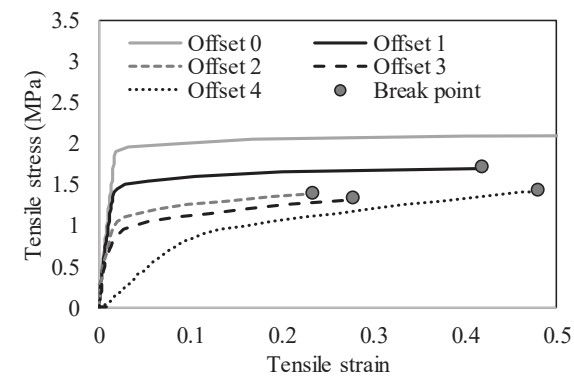

(a) $S_{2}=3.0$

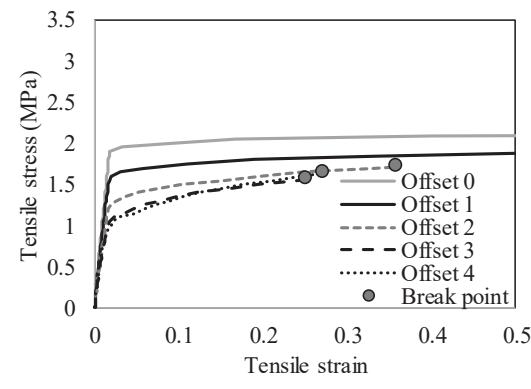

(b) $S_{2}=5.0$

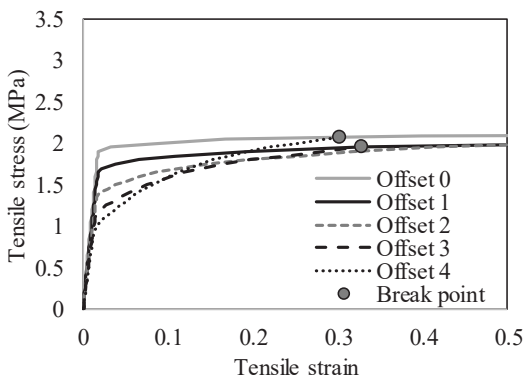

(c) $S_{2}=8.3$

Fig. 9 Tensile stress - tensile strain relationship (Small range of tensile strain) 


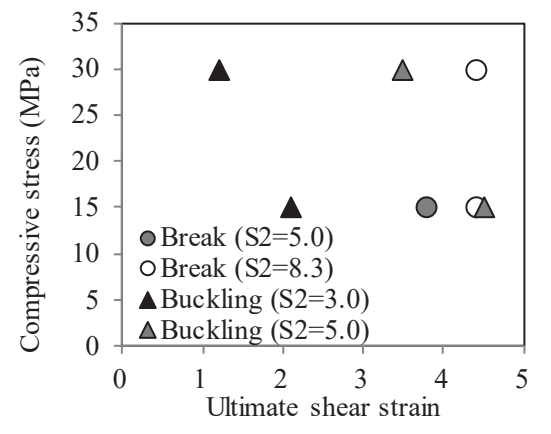

Fig. 10 Shear break strain under bi-directional loading and buckling strain

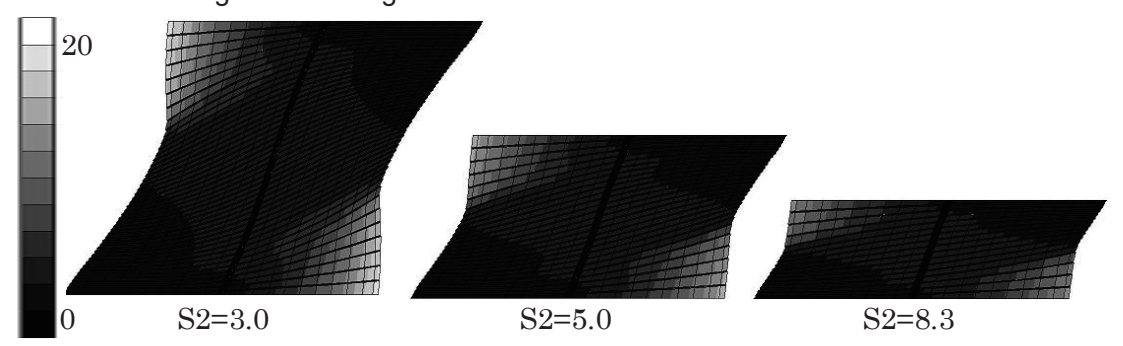

Fig. 12 Maximum principal strain (Tensile loading)

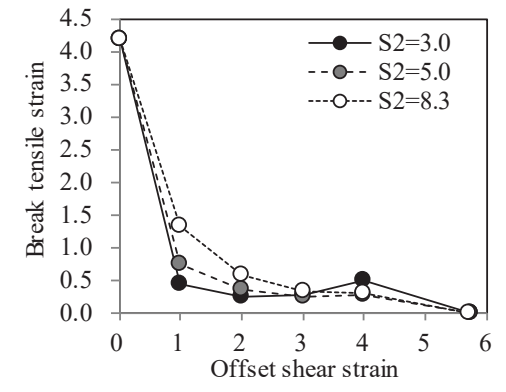

(a) Break strain

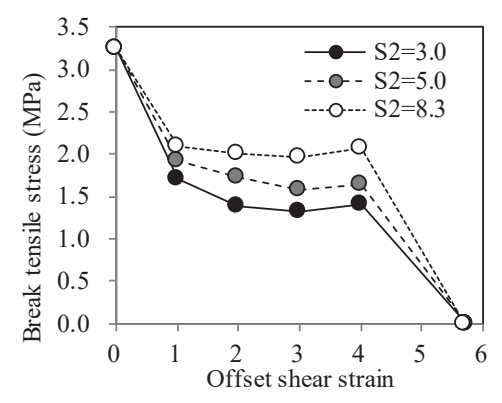

(b) Break stress

Fig. 11 Tensile break strain

\section{5. まとめ}

「せん断破断」「引張破断」「座屈」の 3 つの終局特性に注目し、 高減衰ゴム系積層ゴムを対象に、その終局特性を有限要素法で高精 度に予測する解析モデルを提案した。高減衰ゴム系積層ゴムにおい ては、「せん断破断」、「引張破断」「座屈」を同時に予測可能な高減 衰ゴム材料の材料モデルが存在しない課題があった。そこで、本研 究では高減衰ゴムの終局特性を評価可能な材料モデルを提案した。 また試験結果と比較し、解析結果と試験結果が高精度で一致し、提 案した解析モデルの妥当性を確認した。特に FEM 解析結果におい て、文献 9)で見られたように $W_{0}$ を低減不変量で定義した際、オフ セットせん断ひずみを与えて引張加力した時や、大変形加力した時 に、過度に剛性が低下寸る現象も見られなかった。

提案した解析モデルにて、二次形状係数が高減衰ゴム系積層ゴム の終局特性に与える影響を予測した。主な新しい知見を以下に示す。

（1）引張加力において、二次形状係数 $S_{2}$ が小さい程、引張破断特 性が低下寸る。これは、積層ゴム全体の引張ひずみ状態が同じ であっても、 $S_{2}$ が小さい程破断起点における局部的なひずみが 大きくなることが原因である。

（2）水平加力において、 $S_{2}$ が大きいとせん断破断が終局特性とな

りやすく、 $S_{2}$ が小さいと座屈が終局特性となりやすい

(2)は自明の結果ではあるが、有限要素解析によりその傾向を確認 することができた。本研究で実施した予測手法により、方向性のあ る角型積層ゴムや、局所的な引張変形により破断を生じる多段積層 ゴム等、様々な仕様に対する本終局特性予測の応用が可能である。 また、高減衰系積層ゴムだけでなく、天然ゴム系積層ゴムや鉛挿入 型積層ゴムの終局特性も予測可能である。今後、試験結果との比較 による更なる本手法の妥当性検証も必要ではあるが、試験実施が困 難な終局特性を解析で予測できる有用かつ強力な解析手法であると 考えられる。特に、実大試験体の終局特性把握は実施が困難である ため、縮小試験体による終局特性試験から今回提案した解析手法に
おける各種パラメータを決定し、実大試験体の終局特性を予測する ことが合理的である。ただし、その際にはスケール効果の把握が重 要である。スケール効果は非常に重要な課題であり、今回はそのス ケール効果に関しては一切考慮できていない。即ち、破断指標と破 断クライテリア值は試験体サイズによらず一定としている。スケー ル効果も含めて終局特性を予測できる解析モデルの構築も重要な課 題であり、今後は、様々なサイズの試験体による終局特性把握試験 と解析の比較データの蓄積が重要である。

今回の予測手法では、「引張破断」と「座屈」の水平 2 方向加力時 の影響は無視した。水平 2 方向加力の影響を考慮した「引張破断」

と「座屈」の予測手法も今後の課題であると考えられる。

高減衰ゴム系積層ゴムに対する材料モデルの高精度化という観点 からは、本研究では速度依存性や繰返し加力依存性が考慮されてい ない。実大試験体による動的試験が困難であることを考慮すると、 今後は速度依存性のモデル化も課題の一つである。また、高減衰ゴ ム系積層ゴムの繰返し加力に関しては、過去筆者らによって繰返し 加力による性能変化を考慮した材料モデルを提案している18)。その モデルと本研究におけるモデルを組合わせることで、更に高精度な 材料モデルを構築できる可能性がある。

\section{参考文献}

1) Takayama, M., Tada, H., Morita, K.: Experimental Study on Critical Strength of Laminated Rubber Bearings Part2 Results of Experiments, Summaries of Technical Papers of Annual Meeting, Architectural Institute of Japan, B-2, Structure II, pp.595-596, 1991. 7 高山峯夫, 多田英之, 森田慶子：積層ゴムアイソレータの限界耐力に関す る実験研究 (その 2) 実験結果, 日本建築学会大会学術講演梗概集 B- II, pp.595-596, 1991.7

2) Ookouchi, Y., Shimamoto, R., Ishikawa, S., Takeuchi, Y., Inaba, S., Nemoto, T.: A development of base-isolation system applied in large input region. Part5 The ultimate behavior of two-stage rubber bearing, Summaries of Technical Papers of Annual Meeting, Architectural Institute of Japan, B-2, Structure II, pp.1184-1185, 2019.7 
大河内靖雄，島本龍，石川慎也，竹内義高，稲葉学，秋本 高英，根本毅：高 震度地域対応免震システムの開発(その 5) 二段積層ゴムの終局特性，日本 建築学会大会学術講演梗概集 B- II, pp.1184-1185, 2019.7

3) Kelly, J. M., Marsico, M. R.,: STABILITY AND POST-BUCKLING BEHAVIOR IN NONBOLTED ELASTOMERIC ISOLATORS, mathematical sciences publishers + Anti-Seismic Systems International Society, 2010

4) Mori, T., Kato, H., Murota, N.,: FEM ANALYSIS OF HIGH DAMPING LAMINATED RUBBER BEARINGS USING AN ELASTIC-PLASTIC CONSTITUTIVE LAW OF THE DEFORMATION HISTORY INTEGRAL TYPE, Journal of Structural and Construction Engineering (Transactions of AIJ), Vol.75, No.658, pp.2171-2178, 2010. 12 森隆浩, 加藤秀章, 室田伸夫：変形履歴積分型の弾塑性構成則を用いた高 減衰積層ゴムの FEM 解析, 日本建築学会構造系論文集, 第 75 巻, 第 658 号, pp.2171-2178, 2010.12

5) Mori, T., Nakamura, M., Murota, N., Kitamura, H., Sato, T.,: EXPERIMENTAL STUDY ON INFLUENCE OF DYNAMIC COMPONENT OF WIND LOADING ON RESPONSE CHARACTERISTICS OF HIGH DAMPING RUBBER BEARINGS AND MODELING FOR WIND RESPONCE ANALYSIS, Journal of Structural and Construction Engineering (Transactions of AIJ), Vol.77, No.676, pp.823-832, 2012.6

森隆浩, 加藤秀章, 竹内貞光, 菊地隆志, 室田伸夫：風荷重の動的成分が高 減衰系積層ゴムの応答特性に与える影響に関する実験的研究及びその解析 モデルの検討, 日本建築学会構造系論文集, 第 77 巻, 第 676 号, pp.823$832,2012.6$

6) Kato, H., Mori, T., Murota, N., Ishii, K., Kikuchi, M.: A HYSTERESIS MODEL OF HIGH-DAMPING RUBBER BEARINGS USING AN INTEGRAL TYPE DEFORMATION HISTORY CONSTITUTIVE LAW, Journal of Structural and Construction Engineering (Transactions of AIJ), Vol.76, No.667, pp.1721-1728, 2011. 9

加藤秀章, 森隆浩, 室田伸夫, 石井建, 菊地優: 高減衰積層ゴムの変形履歴 積分型復元力モデルに関する研究, 日本建築学会構造系論文集, 第 76 巻, 第 667 号, pp.1721-1728, 2011.9

7) Mori, T., Murota, N., Kikukchi, T., FEM ANALYSIS OF THE LAMINATED RUBBER BEARINGS UNDER TENSILE AND LARGE HORIZONTAL DEFORMATION USING THE HYPERELASTIC CONSTITUTIVE LAW WITH STIFFNESS DEGRADATION DUE TO GENERATION OF VOIDS IN RUBBER, Journal of Structural and Construction Engineering (Transactions of AIJ), Vol.76, No.663, pp.917$925,2011.5$

森隆浩, 室田伸夫, 菊地隆志：ボイド発生によるゴムの剛性低下を考慮し た超弾性構成則による積層ゴムの引張り変形及び水平大変形 FEM 解析, 日本建築学会構造系論文集，第 76 巻，第 663 号, pp.917-925, 2011.5

8) Mori, T., Nakagawa, S, Shimamoto, R., Murota, N, Kondo, A., Nakayama, T.: Mechanical characteristics of two-tiered laminated rubber bearings for actualizing large deformation capacity. Part 7 Horizontal and tensile deformation analysis based on FEM model., Summaries of Technical Papers of Annual Meeting, Architectural Institute of Japan, B-2, Structure II , pp.503-504, 2011.7

森隆浩, 中川進一郎, 島本龍, 室田伸夫, 近藤明洋, 中山尚之: 高い変形能 力を有する 2 段組積層ゴムの力学挙動(その 7) FEM モデルによる水平変 形 - 引張変形解析, 日本建築学会大会学術講演梗概集 B-II, pp.503-504, 2011.7

9) Mori, T., Nakamura, M., Murota, N., Kitamura, H., Sato, T.,: EVALUATION OF TENSILE CHARACTERISTICS OF RUBBER BEARINGS TO DESIGN SEISMICALLY ISOLATED STRUCTURE BY DESIGN LIMIT VALUE OF TENSILE STRAIN, Journal of Structural and Construction Engineering (Transactions of AIJ), Vol.80, No.718, pp.2021-2031, 2015.12

森隆浩, 中村昌弘, 室田伸夫, 北村春幸, 佐藤利昭: 引張限界ひずみによる 免震構造物設計のための積層ゴムの引張特性の評価, 日本建築学会構造系 論文集，第 80 巻，第 718 号, pp.2021-2031, 2015.12

10) Mori, T., Masaki, N., Murota, N., Ikeda, M., Kosugi, S., Imaoka, T., Shimizu, H., Jimbo, M., Umeki, Y.: SIMULATION OF ULTIMATE CHARACTERISTICS OF LARGE SCALE SEISMIC ISOLATOR BASED
ON LARGE DEFORMATION FINITE ELEMENT ANALYSIS, Journal of Structural and Construction Engineering (Transactions of AIJ), Vol.82, No.735, pp.663-673, 2017.5

森隆浩，正木信男，室田伸夫，池田正樹，小杉慎司，今岡哲男，清水弘，神 保雅一, 梅木芳人: 有限要素法による実規模免震装置の終局特性シミュレ ーション，日本建築学会構造系論文集，日本建築学会構造系論文集，第 82 巻, 第 735 号, pp.663-673, 2017.5

11) Fukasawa, T., Okamura, S., Yamamoto, T., Hirotani, T., Moriizumi, E., Sakurai, Y., Mori, T., Masaki, N.,: ULTIMATE CHARACTERIZATION OF HALF SCALE MODEL THICK RUBBER BEARINGS FOR SFR, Journal of Structural and Construction Engineering (Transactions of AIJ), Vol.82, No.740, pp.1641-1651, 2017.10

深沢剛司，岡村茂樹，山本智彦，廣谷勉，森泉瑛里子，櫻井祐，森隆浩，正 木信男：高速炉に適用する厚肉積層ゴムの $1 / 2$ 縮尺試験体を用いた終局特 性評価, 日本建築学会構造系論文集, 第 82 巻, 第 740 号, pp.1641-1651, 2017.10

12) Inaba, S., Takeuchi, Y., Akimoto, T., Umeki, Y., Ookouchi, Y., Miyazaki, T.: A development of base-isolation system applied in large input region. Part4 The influence of middle flange of two-stage rubber bearing, Summaries of Technical Papers of Annual Meeting, Architectural Institute of Japan, B-2, Structure II , pp.1184-1185, 2017.7

稲葉学, 竹内義高, 秋本 高英, 梅木芳人, 大河内靖雄, 宮崎瑞恵: 高震度地 域対応免震システムの開発(その4) 二段積層ゴム中間フランジの影響検討, 日本建築学会大会学術講演梗概集 B- II, pp.1184-1185, 2017.7

13) Mori, T., Kato, H., Kikuchi, T., Nakamura, M., Murota, N.,: Material model for high damping rubber bearings with the effect of stiffness degradation under tensile loading., Summaries of Technical Papers of Annual Meeting, Architectural Institute of Japan, B-2, Structure II , pp.373-374, 2013.7

森隆浩, 加藤秀章, 菊地隆志, 中村昌弘, 室田伸夫：引張による剛性低下を 考慮した高減衰積層ゴムの材料モデル, 日本建築学会大会学術講演梗概集 B- II , pp.373-374, 2013.7

14) Mori. T., Kato, Murota, N.,: Prediction of second shape factor dependence on tensile break property of seismic isolator based on FEA., Summaries of Technical Papers of Annual Meeting, Architectural Institute of Japan, B-2, Structure II , pp.99-100, 2019. 7

森隆浩, 室田伸夫: FEM による 2 次形状係数が積層ゴムの引張破断特性に 与える影響予測, 日本建築学会大会学術講演梗概集 B- II, pp.99-100, 2019.7

15) Yamamoto, M., Minewaki, S., Yoneda, H., Higashino, M.: FULLSCALE TESTS AND ANALYTICAL MODEL OF HIGH-DAMPING RUBBER BEARINGS USING TWO HORIZONTAL DIRECTIONAL LOADING, Journal of Structural and Construction Engineering (Transactions of AIJ), Vol.74, No.638, pp.639-645, 2009.4

山本雅史, 嶺脇重雄, 米田春美, 東野雅彦: 高減衰ゴム支承の水平 2 方向加 力時の力学特性に関する実大実験及びモデル化, 日本建築学会構造系論文 集, 第 74 巻, 第 638 号, pp.639-645, 2009.4

16) Kato, H., Mori, T., Murota, N., Suzuki, S., Minewaki, S., Yamamoto, M., Yoneda, H., Higashino, M.: AN EXPERIMENTAL AND ANALYTICAL STUDY ON ULTIMATE PROPERTIES OF SEISMIC RUBBER BEARINGS UNDER HORIZONTAL BIAXIAL LOADING, AIJ Journal of Technology and Design, Vol.16, No.32, pp.167-172, 2010.2 加藤秀章, 森隆浩, 室田伸夫, 鈴木重信, 嶺脇重雄, 山本雅史, 米田春美, 東野雅彦: 免震用積層ゴムの 2 方向加力時の限界特性に関する研究，日本 建築学会技術報告集, 第 16 巻, 第 32 号, pp.167-172, 2010.2

17) Hisada, T.: Base of Tensor analysis for Non-Linear Finite Elemnt Analysis, Maruzen Co., 1999.9

久田俊明: 有限要素法のためのテンソル解析の基礎, 丸善, 1999.9

18) Mori, T., Kato, H., Murota, N.,: MODELING FOR ANALYSIS OF HIGH DAMPING RUBBER BEARINGS WITH EFFECTS OF FATIGUE AND TEMPERATURE INCREASE DUE TO REPEATED DEFORMATION, Journal of Structural and Construction Engineering (Transactions of AIJ), Vol.77, No.680, pp.1517-1526, 2012. 10 森隆浩, 加藤秀章, 室田伸夫：繰返し変形による疲労と温度上昇の効果を 取り入れた高減衰積層ゴムの解析モデルの検討, 日本建築学会構造系論文 集，第 77 巻，第 680 号, pp.1517-1526, 2012.10 
EXPERIMENTAL AND ANALYTICAL STUDY ON ULTIMATE PROPERTY OF RUBBER BEARINGS

Proposal of material model to predict ultimate property and prediction analysis of break and buckling property for high-damping rubber bearings

Takahiro MORI ${ }^{* 1}$ and Nobuo MUROTA*2

${ }^{* 1}$ Bridgestone Corporation, Seismic Isolation and Vibration Control Products Development Dept., Dr.Sci.
${ }^{* 2}$ Bridgestone Corporation, Seismic Isolation and Vibration Control Products Development Dept., Ph.D.

Rubber bearing is one of measure isolation devices and there are many types of rubber bearing. For example, natural rubber bearings, lead rubber bearings, high-damping rubber bearings and elastomeric sliding bearings are major devices in Japan. Rubber bearings support upper structure under high vertical loading, therefore, it is very important to understand ultimate property and margin to the ultimate state to design seismically isolated structures properly. However, it is difficult to carry out ultimate property test using full-scale specimen because large scale testing machine is needed. One of the alternative method to predict performance of rubber bearings is analysis approach and finite element analysis is one of the most popular methods. Therefore authors propose analysis model to predict ultimate property of rubber bearings based on finite element analysis. In this study, proposed method is mainly focused on highdamping rubber bearings. One of the important feature of high-damping rubber bearings is that the high-damping rubber has the functions of both damping and restoring force. First, new material model for high-damping rubber bearing to predict ultimate property and ultimate property prediction method are proposed. Second, analytical example to predict second shape factor dependence of ultimate property is introduced.

Regarding rubber bearings there are various modes of ultimate state such as break under large horizontal deformation (horizontal break), break under large tensile deformation (tensile break), break under large vertical compression, buckling and roll-out. In this study, ultimate property prediction method using is proposed focusing on three ultimate modes of horizontal break, tensile break and buckling. In the case of finite element analysis, it is very important to selection material model for rubber properly. Regarding high-damping rubber bearing, however, there was no proper material model to predict ultimate property mentioned above. Therefore, new material model for highdamping rubber bearing to predict ultimate property is proposed in this paper. By comparing analysis and experiment result, validity of proposed material model for high-damping rubber bearing is shown.

In the past, as for lead rubber bearings, authors showed the various factor dependence of ultimate property. The factors are number of lead plugs, diameter of lead plug, insert plate thickness, shear modulus variability of rubber and break strain variability of rubber. In this study, authors show second shape factor $\left(S_{2}\right)$ dependence of ultimate property. As a result of proposed analysis, obtained main findings are as follows;

A. Under tensile loading, as second shape factor $S_{2}$ is smaller, tensile break strain is decrease.

B. Under horizontal loading, as second shape factor is small, buckling mode tends to be dominant. And as second shape factor is large, break mode tends to be dominant

Findings B is obvious conclusions, however, the tendencies were predicted by finite element analysis using proposed method in this study. 